Original Article

\title{
Angiotensin converting enzyme gene polymorphism in dyslipidemia and hypertension
}

Nagham Y. Mohamed ${ }^{1}$, Laila H. Fawzy ${ }^{2}$, Asmaa S. Hasan ${ }^{2}$

${ }^{1}$ Clinical Pathology Department, Student hospital, Helwan University, Helwan, Egypt. ${ }^{2}$ Clinical Pathology Department, Faculty of Medicine for Girls, Cairo, Al-Azhar University, Egypt

\begin{abstract}
Background: Hypertension and dyslipidemia have a multifactorial background based on genetic and environmental interactive factors. Increasing blood pressure (BP) and hypertension incidence have also been found to be linked with elevated blood lipids rates. Insertion/deletion (I/D) polymorphisms of the angiotensin converting enzyme (ACE) are said to be linked to pathogenesis of both hypertension and dyslipidemia.
\end{abstract}

Objectives: to investigate the presence of the three genotypes of ACE gene (I/D) polymorphisms with hypertension and dyslipidemia.

Subjects and methods: Participants included 30 Egyptian patients with hypertension and /or dyslipidaemia (Group I) and 20 apparently healthy controls (Group II). For all participants, DNA was isolated and amplified by polymerase chain reaction (PCR); the product was recognized by gel electrophoresis according to their size.

Results: diferent ACE genotypes frequencies were detected according to the presence or absence of $287 \mathrm{bp}$ fragment in intron 16; 30\% for Deletion/Deletion (DD), 56.7\% for Insertion/Deletion (ID) and 13.3\% for Insertion/Insertion (II) in patients group, denoting that (I) allele has a significant association with hypertension and dyslipidemia $(\mathrm{p}<0.05)$.

Conclusions: There is increased frequency of ACE I/D and I/I, therefore, the I allele was common among Egyptian patients affected with hypertension and /or dyslipidaemia.

JRAM 2021; 2 (1): 30-36

Keywords: ACE, dyslipidaemia, Egypt, hypertension, polymorphism.

Submission Date: 22 July 2020

Acceptance Date: 1 September 2020

Corresponding Author: Nagham Yousef Mohamed, clinical pathology department, student hospital, Helwan University, Helwan, Egypt. Tel: 01062765294. Email: drnaghamyousef@ hotmail.com

Please cite this article as: Mohamed NY, Fawzy LH, Hasan AS, Angiotensin converting enzyme gene polymorphism in dyslipidemia and hypertension. JRAM 2021; 2 (1): 30-36. DOI: 10.21608/jram.2020.33184.1064

\section{INTRODUCTION}

Hypertension and dyslipidemia are risk factors contribute to cardiovascular disease. Hypertension and dyslipidemia coexistence is often observed in either mixed or sporadic in daily clinical practice ${ }^{[1]}$.

Epidemiological studies have documented that hypertension prevalence is associated with increased levels of lipids in the blood ${ }^{[2]}$. Coincident genetic factors, such as having chromosomal regions, predispose for the occurrence of hypertension and dyslipidemia at the same time, for example locus on chromosome 1q21-q23 has been linked in various genome scans to familial combined hyperlipidemia, and blood pressure ${ }^{[3]}$.

Hypertension and dyslipidemia share similar pathophysiological conditions such as obesity and diabetes mellitus (DM) and consequent dysregulation of adipocytokines release from adipose tissues. In addition, atherosclerosis is adversely affected by dyslipidemia due to its functional and structural arterial properties. These changes may impair the regulation of $\mathrm{BP}$ and, in turn, development of hypertension in dyslipidemic patients ${ }^{[4]}$.Also, impaired ReninAngiotensin- Aldosterone System (RAAS) is considered as significant factor in the pathogenesis of type 2 DM as RAAS blockade by ACE inhibitors reduce the incidence ${ }^{[5]}$.

The RAAS genes are the applicant genes that define hypertension and risk of developing cardiovascular disorders that have genetic encoding components. The insertion/deletion (I/D) polymorphism of the angiotensin - converter enzyme (ACE) is among the multiple genetic polymorphisms identified and that have an effective role in pathogenesis of hypertension 
and cardiovascular diseases ${ }^{[6]}$. The ACE is a key component of RAAS which regulates BP by the regulation of body fluid volume. It transforms angiotensin I to the active form; angiotensin II vasoconstrictor. ACE thus raises $\mathrm{BP}$ indirectly, by causing blood vessels vasoconstriction ${ }^{[7]}$. The ACE is present also in endothelial and kidney epithelial cells but located mainly in the capillaries of the lungs. The degradation of bradykine and amyloid beta-protein are other features of a less common ACE function ${ }^{[8,9]}$. The ACE gene is found in chromosome 17q23 with 26 exons and 25 introns in total length of $21 \mathrm{~kb}$. The I/D polymorphism exist, depending on whether a fragment of $287 \mathrm{bp}$ is present in Intron 16. In certain research, three forms of genotypes were confirmed: insertion/deletion (I/D), deletion/deletion (D/D), and insertion/insertion $(\mathrm{I} / \mathrm{I})^{[10]}$. The aim of this study was to investigate the presence of the three genotypes of ACE gene (I/D) polymorphisms with hypertension and dyslipidemia

\section{SUBJECTS AND METHODS}

A case-control study design was carried out on 30 patients with hypertension and/or dyslipidemia (Group I) and 20 apparently healthy subject (Group II) who were collected randomly and served as controls (they were presented to cardiology clinic for routine medical checkup), they were age and gender matched, and both groups were recruited from cardiology clinic, Helwan University Hospital in the period from February 2018 to January 2020. The Study was approved by local ethical committee of faculty of medicine for girls, Cairo, Al-Azhar University, Egypt. Written conformed approval consent was obtained from all study subjects. Molecular investigations were done in Clinilab in collaboration with clinical pathology department, faculty of medicine for girls, Cairo, Al-Azhar University, Egypt.

\section{Exclusion criteria}

Patients with DM, autoimmune diseases as well as renal disease were excluded from the study.

All subjects included in the study were subjected to complete history taking with special emphasis on: age, duration of hypertension and dyslipidemia, history of treatment therapy for both dyslipidemia and hypertension, family history of hypertension and dyslipidemia was reported and family history of other diseases was taken. Full clinical examination and measurements of BP were done for all subjects. Patients were chosen with seated systolic blood pressure (SBP) was $\geq 140 \mathrm{mmHg}$ and/or diastolic blood pressure $(\mathrm{DBP}) \geq 90 \mathrm{mmHg}$ on at least three occasions.

\section{Sample Collection and processing}

Five $\mathrm{ml}$ of venous blood were withdrawn under complete aseptic conditions from patients and controls after 10 hours fasting, three $\mathrm{ml}$ used for lipid profile determination (total cholesterol (TC)(mg/dl) , triglycerides (TG) $(\mathrm{mg} / \mathrm{dl})$, high density lipoprotein cholesterol (HDL-C)(mg/dl) by enzymatic colorimetric method, two $\mathrm{ml}$ of blood were collected into EDTA vactainers and stored at $-20^{\circ} \mathrm{C}$ for DNA extraction and polymerase chain reaction (PCR) to determine the three genotypes of ACE gene (I/D) polymorphism .

\section{Molecular analysis of blood sample}

1. DNA extraction: Genomic Deoxy-ribonucleic acid (DNA) was obtained from the peripheral blood leucocytes by QIAamp DNA Blood Mini Kit, (QIAGEN) (Germany) (Cat.No. 51104). NanoDrop spectrophotometer were used to measure concentration and purity .Values less than 1.7 indicate protein contamination of DNA in early extraction steps while values more than 1.9 , indicate DNA contamination with ethanol or other buffer remnants used in the extraction steps.

2. ACE (I/D) genotyping by thermal cycler Polymerase Chain Reaction: the genomic DNA fragment on the inron 16 of ACE gene $(287 \mathrm{bp})$ in intron 16 of ACE gene were amplified with Upstream primer 5'CCCAGGCCG GGGACTCTGTA-3'; and downstream primer 5'AGCTCCAGCCCTTAGCTCACCT3'.

- PCR was carried out using Taq PCR Master Mix Kit, (Cat.No.201443) (QIAGEN containing Taq DNA Polymerase, Qiagen PCR Buffer (KCL and NH4SO4), ultrapure dNTPs (deoxy-ribonucleotide triphosphate and $\mathrm{MgCl} 2$ ).

- A final volume of $25 \mu 1$ were used for the PCR reaction including; $12.5 \mu \mathrm{l}$ Master Mix, $1 \mu 1$ forward primer, $1 \mu 1$ reverse primer, calculated sample volume containing $150 \mathrm{ng}$ DNA equal to measured concentration of DNA in each sample by Nanodrop X volume of sample withdrawn. Add distilled water to complete total volume to $25 \mu \mathrm{l}$ :

- Initial denaturation were the first step of Thermal cycling conditions of PCR reaction at $94^{\circ} \mathrm{C}$ for 4 minutes to ensure that template DNA and primes are denaturated and became single stranded, followed by 36 cycles of denaturation at $94^{\circ} \mathrm{C}$ for 50 seconds, annealing by gradual cooling of temperature at $58^{\circ} \mathrm{C}$ for 30 seconds, then, extension at $72^{\circ} \mathrm{C}$ for 60 seconds and final extension at $72^{\circ} \mathrm{C}$ for 5 minutes. Once the amplicons were obtained, they were run in parallel on $2 \%$ agarose gel electrophoresis which used as a diagnostic tool to visualize the amplified fragment by including in the gel intercalating dye, ethidium bromide. Illumination with ultraviolet light causes the intercalated dye to produce fluorescence. In order to estimate the size of PCR products, a ladder of 100 base pair (bp) was loaded into the gel, which were of $190 \mathrm{bp}$ for D allele and 490 bp for I allele (figure 1).

\section{Statistical analysis}

Data was managed using IBM SPSS statistics (V. 25.0, IBM Corp., USA, 2017-2018). Data were expressed as Mean \pm SD for quantitative parametric data in addition to 
both number and percentage for categorized data. Student's t- used to compare two quantitative data when samples are collected independently of one another. Chi square $\left(x^{2)}\right.$ test used to compare proportions between two qualitative parameters The data were considered significant if $\mathrm{p}$ values were less than 0.05 and as considered highly significant if $\mathrm{p}$ values were less than $<0.001$, and non-statistically significant if $\mathrm{P}$ value $>0.05$. Odd's ratio $(\mathrm{OR})$ at $95 \%$ Confidence Intervals (CI) was used as a measure of association between an exposure and an outcome.

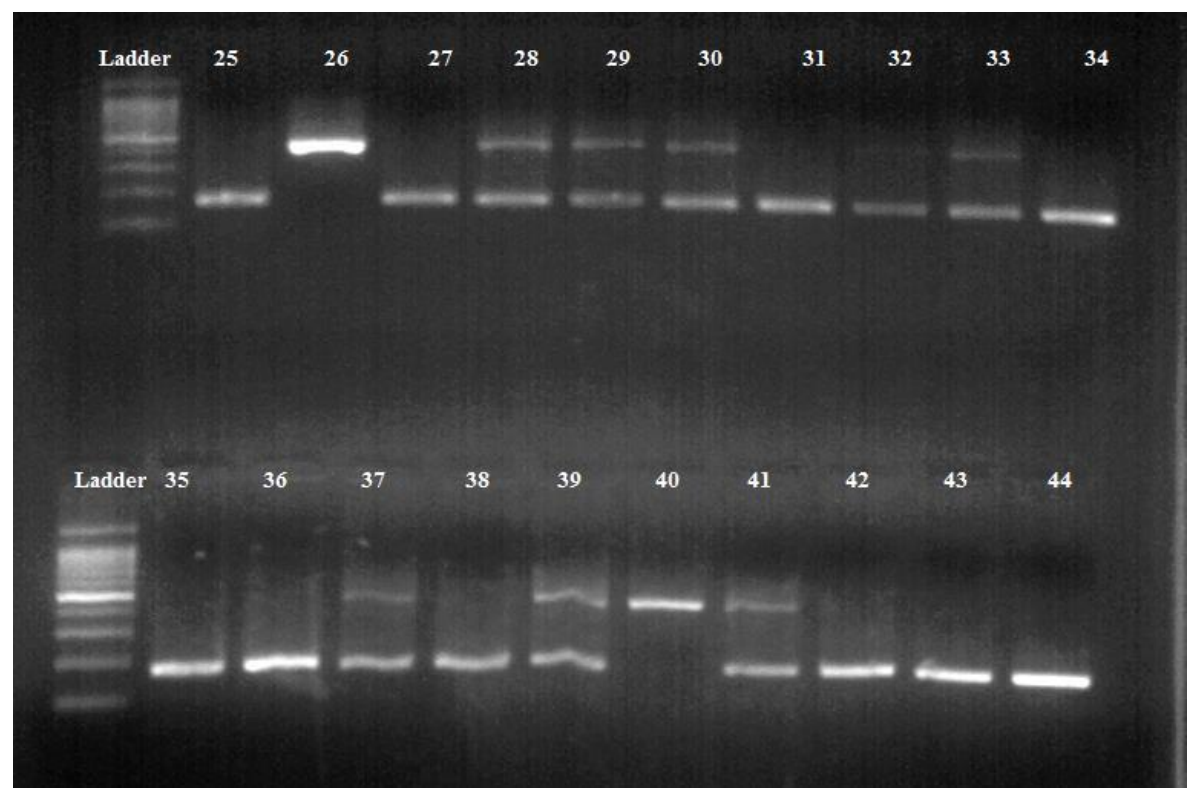

Figure (1) Gel electrophoresis showing both II , ID and DD genotypes of ACE gene polymorphism.

The genotyping resulting by $2.0 \%$ agarose gel electrophoresis

\section{RESULTS}

Patients and controls demographic and clinical characteristics are demonstrated in table (1).

Comparison revealed that mean systolic pressure (SBP), diastolic blood pressure (DBP), Total TC levels, TG and LDL were significantly higher; while HDL-C was lower in patients than in controls, $p<0.001$ (Table 2), family history of hypertension showed significant increase in patients compared to controls $(\mathrm{p}<0.001)$, while family history of dyslipidemia, didn't differ between both groups $(\mathrm{p}<0.05)$

Comparison study showed a statistically significant higher expression of heterozygous genotype I/D distribution in patients group compared to control group (56.7 \% vs. $30 \%, \mathrm{p}<0.05)$. In addition, patients showed statistically significant increase in I/I genotype distributions $(13.3 \%$ vs. $5 \%, \mathrm{p}<0.05)$. However, there was a statistically significant decreased expression of D/D genotype in patients group compared to control group $(30 \%$ vs. $65 \%, \mathrm{p}<0.05)$ (Table 3 )

There was a significant higher frequency of the ACE I allele in patients group compared to control group (41.67\% vs. $20 \%, \mathrm{p}<0.05)$. However, a significant decrease was observed in D allele in patients group compared to control $(58.33 \%$ vs. $80 \%$ p <0.05) (Table 4)

Table (1): Comparison of age and sex between studied groups

\begin{tabular}{|l|c|c|c|c|}
\hline $\begin{array}{l}\text { Demographic Data } \\
\text { Age (years) }\end{array} \quad$ Patients(N=30) & Control $(\mathbf{N}=\mathbf{2 0})$ & $\mathbf{t} / \mathbf{X}^{\mathbf{2}}$ & P value \\
\hline $\begin{array}{l}\text { Mean } \pm \text { SD } \\
\text { Range }\end{array}$ & $54.47 \pm 6.9$ & $55 \pm 6.6$ & 0.3 & 0.785 \\
\hline $\begin{array}{l}\text { Sex } \\
\quad \text { Male }\end{array}$ & $43-70$ & $43-64$ & & \\
$\quad$ Female & $16(53.3 \%)$ & $11(55 \%)$ & & \\
\hline
\end{tabular}


Table (2): Comparison of SBP, DBP, TC, TG, HDL and LDL between studied groups

\begin{tabular}{|c|c|c|c|c|}
\hline Laboratory Data & Patients $(\mathbf{N}=\mathbf{3 0})$ & Control $(\mathrm{N}=20)$ & t-test & $P$ value \\
\hline $\begin{array}{l}\text { SBP }(\mathbf{m m H g}) \\
\text { Mean } \pm \text { SD } \\
\text { Range }\end{array}$ & $\begin{array}{l}148.17 \pm 19 \\
120-190\end{array}$ & $\begin{array}{l}117.75 \pm 9 \\
100-130\end{array}$ & 7.6 & $0.001 * *$ \\
\hline $\begin{array}{l}\text { DBP }(\mathbf{m m H g}) \\
\text { Mean } \pm \text { SD } \\
\text { Range }\end{array}$ & $\begin{array}{l}93.5 \pm 14 \\
80-130\end{array}$ & $\begin{array}{l}76 \pm 5 \\
70-80\end{array}$ & 6.2 & $0.001 * *$ \\
\hline $\begin{array}{l}\text { TC } \mathbf{~ m g / d l} \\
\quad \text { Mean } \pm \text { SD } \\
\text { Range }\end{array}$ & $\begin{array}{l}222.27 \pm 71.2 \\
130-440\end{array}$ & $\begin{array}{l}152.65 \pm 8 \\
139-167\end{array}$ & 5.3 & $0.001 * *$ \\
\hline $\begin{array}{l}\text { TG mg/dl } \\
\text { Mean } \pm \text { SD } \\
\text { Range }\end{array}$ & $\begin{array}{l}177.57 \pm 63 \\
90-300\end{array}$ & $\begin{array}{l}106.8 \pm 11 \\
94-131\end{array}$ & 6.0 & $0.001 * *$ \\
\hline $\begin{array}{l}\text { HDL } \mathbf{~ m g / d l} \\
\text { Mean } \pm \text { SD } \\
\text { Range }\end{array}$ & $\begin{array}{l}46.77 \pm 14.5 \\
33-80\end{array}$ & $\begin{array}{l}66.1 \pm 5 \\
55-74\end{array}$ & -6.7 & $0.001 * *$ \\
\hline $\begin{array}{l}\text { LDL } \mathbf{~ m g / d l} \\
\quad \text { Mean } \pm \text { SD } \\
\text { Range }\end{array}$ & $\begin{array}{l}140.47 \pm 74 \\
47-368\end{array}$ & $\begin{array}{l}65.7 \pm 6.2 \\
53-76\end{array}$ & 5.5 & $0.001 * *$ \\
\hline
\end{tabular}

Table (3): Comparison of distribution of different ACE genotypes between patients' group and control group

\begin{tabular}{|c|c|c|c|c|}
\hline Genotype & $\begin{array}{c}\text { Patients }(\mathbf{N}=\mathbf{3 0}) \\
\text { No. }(\mathbf{\%})\end{array}$ & $\begin{array}{c}\text { Control }(\mathbf{N = 2 0} \\
\text { No. }(\%)\end{array}$ & $\mathbf{X}^{\mathbf{2}}$ & P value \\
\hline D/D & $9(30.0 \%)$ & $13(65.0 \%)$ & & \\
\hline I/D & $17(56.7 \%)$ & $6(30.0 \%)$ & 6.029 & $0.05 *$ \\
\hline I/I & $4(13.3 \%)$ & $\begin{array}{c}1(5.0 \%) \\
*\end{array}$ & & \\
\hline
\end{tabular}

Table (4): Comparison of ACE gene allele frequencies between patients group and control group

\begin{tabular}{|c|c|c|c|c|}
\hline Allele & Patients $(\mathbf{N}=\mathbf{6 0})$ & Control $(\mathbf{N}=\mathbf{4 0})$ & Z-test & p-value \\
\hline Deletion & $35(58.33 \%)$ & $32(80 \%)$ & 2.257 & $0.05^{*}$ \\
\hline Insertion & $25(41.67 \%)$ & $8(20 \%)$ & 2.257 & $0.05^{*}$ \\
\hline
\end{tabular}

\section{DISCUSSION}

The most important risk factors for CVD are dyslipidemia and hypertension. They represent an important component of the Metabolic Syndrome (MS), which were defined by Adult Treatment Panel III. In 1988, dyslipidemia hypertension (DH) term was used for the first time by Williams and associates, in the context of familial $\mathrm{DH}$, that was suggested as a genetic syndrome in about $12 \%$ of essential hypertension patients and $48 \%$ of the hypertensive sib ships, Insulin resistance has been found to coexist in up to $50 \%$ of hypertensive individuals. DH non-family forms are more prevalent than those of the family forms [11]. ACE gene found in chromosome 17q23 and it contains 25 introns and 26 exons, and the total length is $21 \mathrm{~kb}$. There are 3 genotypes (D/D and I/I homozygote, and I/D heterozygote), according to the presence (I allele) or absence (D allele) of a 287 bp Alu repeat sequence in intron $16^{[12]}$. In this case - control study we analysed the relation between the ACE gene polymorphism and the hypertension and dyslipidemia.
In this study, there was a significant increase of ID and II genotype frequency in ACE gene, as well as the frequency of I allele in patients compared to controls.

Proving that ACE gene polymorphism was linked to the pathogenesis of hypertension and dyslipidemia. Bawazier et al. [13] similarly, reported very low Frequency of DD genotype when compared to II and ID genotype in hypertension group in comparison with normotension and prehypertension subject and that Frequency of I allele is higher than D allele. Also, Srivastava et al. [14] demonstrated that I-allele is associated with hypertension. The association of Iallele with hypertension may be due to high levels of thereby resulting in higher heterozygosity. Different other genetic and environmental factors involved in BP regulation can lead to the heterogeneity associated with ACE I / D population with essential hypertension. However, Bonfim-Silva et al. ${ }^{[15]}$ had reported no significant relationship between the ACE I/D polymorphism and hypertension was observed, but there was a higher proportion of the D allele in their 
study. Nápoles et al. ${ }^{[16]}$ also reported no direct effects of the ACE D-allele on the level of BP and hypertension prevalence. Pinheiro et al. ${ }^{[17]}$ also showed that ACE I/D polymorphisms are not associated with the risk to systemic arterial hypertension development. As limitations or complementation of their study, it is important to underline that, in their study, they choose their hypertension patients without exclusion of type 2 diabetes mellitus. On the other hand, several studies demonstrated positive association between ACE gene polymorphism and essential hypertension as regard in this study, but with predominance of DD genotypes and the D allele of the ACE gene. Mengesha et al. ${ }^{[18]}$ found that DD genotypes and the D allele of the ACE gene has strong association with the prevalence of hypertension $(\mathrm{p}<0.05)$.

As limitations or complementation of our study, it is important to underline that, small number of controls in this study may underpowered its results, that is due to technical problems related to material and kits used.

\section{CONCLUSION}

There is increased incidence of II and ID genotypes of ACE gene polymorphisms in hypertensive and dyslipidemic Egyptian patients which suggests their possible role in hypertension and dyslipidemia pathophysiology. Also, the study documented the increased frequency of I allele in hypertensive and dyslipidemic patients

Financial support: This study did not receive any specific grant from funding agencies in the public, commercial, or not -for profits sectors.

Conflicts of interest: There are no Conflicts of Interest.

\section{REFERENCES}

1. Kario K, Saito I, Kushiro T, Teramukai S, Ishikawa Y, Mori Y, et al. Home blood pressure and cardiovascular outcomes in patients during antihypertensive therapy: primary results of HONEST, a large-scale prospective, real-world observational study. Hypertension 2014; 64:989996.

2. Okamura T, Tanaka H, Miyamatsu N, Hayakawa T, Kadowaki T, Kita Y, et al. The relationship between serum total cholesterol and all-cause or cause-specific mortality in a 17.3-year study of a Japanese cohort. Atherosclerosis 2007; 190:216-223.

3. Shi G, Gu CC, Kraja AT, Arnett DK, Myers RH, Pankow JS, et al . Genetic effect on blood pressure is modulated by age: the Hypertension Genetic Epidemiology Network Study. Hypertension 2009; 53:35-41.

4. McGill JB, Haffner S, Rees TJ, Sowers JR, Tershakovec AM and Weber M. Progress and controversies: treating obesity and insulin resistance in the context of hypertension. J ClinHypertens (Greenwich) 2009; 11:36-41.
5. Kumar R, Singh VP and Baker KM. The intracellular renin-angiotensin system in the heart. Curr Hypertens Rep 2009; 11 (2): 104-110

6. Hsu CH. Different impacts of metabolic syndrome components on insulin resistance in type 2 diabetes. International Journal of Endocrinology 2013; (6):7 pages.

7. Zhang C, Wu S and Xu D. Catalytic mechanism of angiotensin-converting enzyme and effects of the chloride ion. The Journal of Physical Chemistry 2013 B. 117 (22): 6635-45.

8. Fillardi P. ACEi and ARBS in hypertension and heart failure. Volume 5. Switzerland: Springer International Publishing 2015; 10-13.

9. Hemming ML and Selkoe DJ. Amyloid betaprotein is degraded by cellular angiotensinconverting enzyme (ACE) and elevated by an ACE inhibitor. The Journal of Biological Chemistry 2005; 280 (45): 37644-50.

10. Chaoxin J, Daili S, Yanxin H, Ruwei G, Chenlong $W$ and Yaobin $T$. The influence of angiotensin-converting enzyme 2 gene polymerphisms on type 2 diabetes mellitus and coronary heart disease. Eur Rev Med PharmacolSci 2013; 17 (19): 2654-2659.

11. Dalal JJ, Padmanabhan TN, Jain P, Patil S, Vasnawala H, Gulati A. LIPITENSION: Interplay between dyslipidemia and hypertension. Indian J Endocrinol Metab 2012;16(2):240-245.

12. Huang $Y$, Li G, Lan $H$, Zhao G, Huang $C$. Angiotensin-converting enzyme insertion/deletion gene polymorphisms and risk of intracerebral hemorrhage: a meta-analysis of epidemiologic studies. J Renin Angiotensin Aldosterone Syst. 2014; 15(1):32-8

13. Bawazier AL, Sja'bani M, Haryana SM, Soesatyo MH, Sadewa AH. Relationship of Angiotensin converting enzyme, gene polymorphism and hypertension in Yogyakarta, Indonesia, Acta Med Indones-Indones. J Intern Med 2010; 42 (4): 192-198

14. Srivastava K, Sundriyal R, Meena PC, Bhatia J, Narang R, and Saluja D. Association of angiotensin converting enzyme (Insertion/ Deletion) gene polymorphism with essential hypertension in northern Indian. Genetic Testing and Molecular Biomarkers 2012;16(3):174-7.

15. Bonfilm-Silva R, Guimarae LO, Santos JS, Pereira BA and Rios DL. Casecontrol association study of polymorphisms in the angiotensinogen and angiotensin-converting enzyme genes and coronary artery disease and systemic artery hypertension in African-Brazilians and Caucasian-Brazilians, Journal of Genetics 2016; 95 (1): 63-69.

16. Nápole OC, Castellanos $M$, RCasalvilla $L L$, Camacho H, Cintad A, Villareal A, et al. ACE I/D polymorphism study in a cuban hypertensive population. Clinica Chimica Actam2007; 378 (12): 112-116.

17. Pinheiro DS, Santos RS, Jardim PCBV, Silva EG, Reis AAS, Pedrino GR, et al. The combination of ACE I/D and ACE2 G8790A 
polymorphisms revels susceptibility to hypertension: A genetic association study in Brazilian patients. PLoS ONE 2019;14(8): e0221248.
18. Mengesha HG, Petrucka $P$, Spence $C$, Tafesse TB. Effects of angiotensin converting enzyme gene polymorphism on hypertension in Africa: A meta-analysis and systematic review. PLoS ONE 2019; 14(2): e0211054. 


\title{
الماخص العربي
}

تعدد الأثكال الجينية لجين الانزيم المحول للأنجيوتنسين في المرضى المصابين بخلل فى نسبة دهون الدم و ارتفاع ضغط اللام

\author{
نغ يوسف محمد1 ، ليلى حسين فوزى 2، اسماء صبحى حسن2 2 \\ 1 قسم الباتولوجيا الاكلينيكية، مستشفى الطلبة، جامعة حلوان، القاهرة، جمهورية مصر العربية.

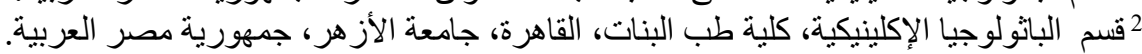

ملخص البحث

الخلفية: يعتبر مرض ارتفاع ضغط الدم وخلل نسبة دهون الدم من الامر اض التي لها عو امل بيئية وجينية

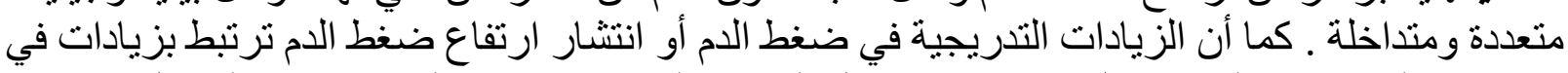

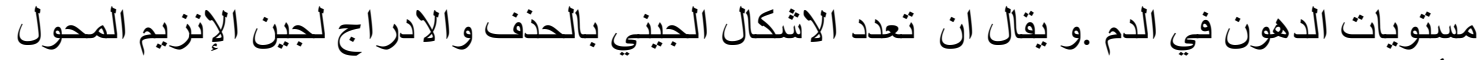

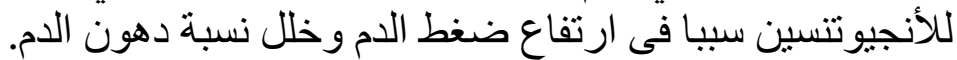

الهرف: تهدف هذه الرسالة الى التحقيق فى وجود علاقة بين وجود الأنماط الجينية الثناثة لتعدد الاشكال الجيني

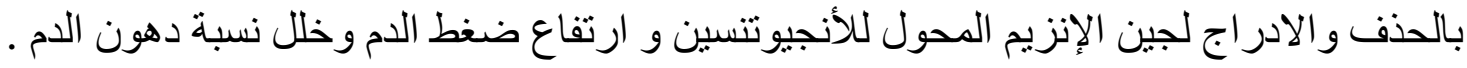

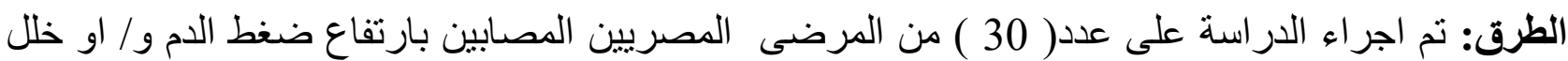

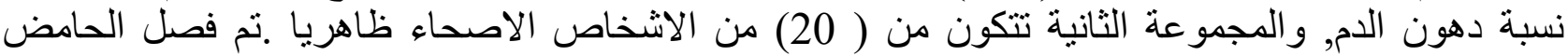
النووي لكل المشاركين فى الدر اسة وتكبيره عن طريق تقنية تفاعل البلمرة التسلسلي و التعرف علئ عليها من خلادل

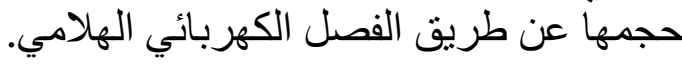

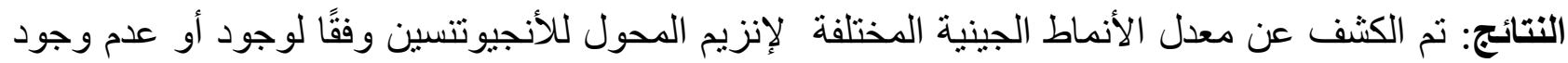
القطعة رقم 287 في الإنترون و كانت النسبة 30\% \% لتعدد الاشكال الجيني حذف/حذف و و 65.7\% لتعدد

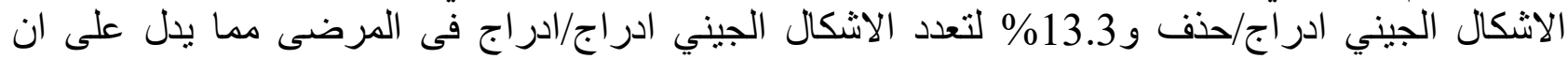

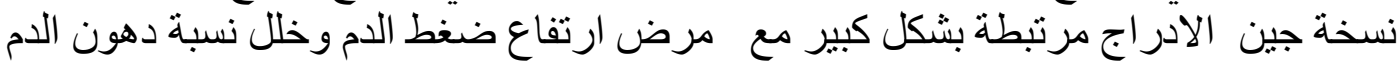

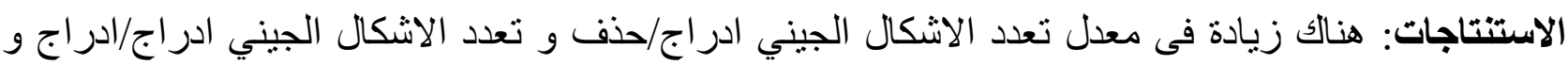

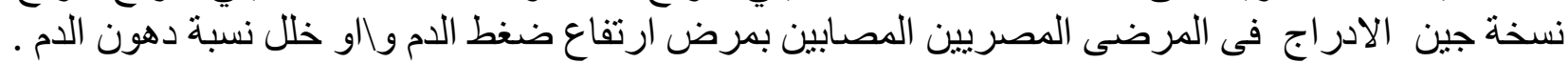

الكلمات الرئيسية: الإنزيم المحول للأنجيوتتسين، خلل نسبة دهون الدم ، مصر، ارتفاع ضغط الدم، تعدد الأشكال الجينية الأبحم: نغم يوسئي محمد، قسم الباثولوجيا الاكلينيكية، مستشفى الطلبة، جامعة حلوان، القاهرة، جمهورية مصر العربية البريد الإكتروني: Email:drnaghamyousef@hotmail.com 